\title{
Influence of Sowing Techniques and Seed Rate on Growth and Yield of Direct Seeded Rice (Oryza sativa L.) under Rainfed Medium Land Situation
}

\author{
K. Nandini Dev ${ }^{1 *}$, Nilanjana Haldar ${ }^{1}$, Herojit Singh Athokpam², K. Khamba Singh ${ }^{3}$, \\ M. Anandi Devi ${ }^{3}$ and A. Dorendro Singh ${ }^{4}$
}

${ }^{1}$ Department of Agronomy, College of Agriculture, Central Agricultural University, Imphal-795004, India

${ }^{2}$ Department of Biochemistry, Manipur College, Imphal-795008, India

${ }^{3}$ Department of Soil Science and Agricultural Chemistry, College of Agriculture, Central Agricultural University, Imphal-795004, India

${ }^{4}$ Department of Botany, Mayai Lambi College, Yumnam Huidrom, Imphal West, Manipur-795009, India

*Corresponding author

\section{A B S T R A C T}

Field experiments were conducted to study the effect of sowing techniques and seed rate on growth and yield of direct seeded rice (Oryza sativa L.) under rainfed medium land

\section{Keywords}

Direct seeded rice,

Line sowing,

Transplanting,

Yield

Article Info

Accepted:

07 July 2019

Available Online:

10 August 2019 situation. The experiment consists of two sowing techniques (Broadcasting and Line sowing) with five seed rate $\left(80 \mathrm{~kg} \mathrm{ha}^{-1}, 90 \mathrm{~kg} \mathrm{ha}^{-1}, 100 \mathrm{~kg} \mathrm{ha}^{-1}, 110 \mathrm{~kg} \mathrm{ha}^{-1}\right.$ and $120 \mathrm{~kg}$ $\mathrm{ha}^{-1}$ ) and replicated thrice in factorial randomised block design. Line sowing with seed rate of $100 \mathrm{~kg} \mathrm{ha}^{-1}$ was found to be superior $\left(6030 \mathrm{~kg} \mathrm{ha}^{-1}\right)$ in grain production over the other combinations. Maximum plant height $(112.29 \mathrm{~cm})$, number of tillers $\mathrm{m}^{-2}(90.40)$, effective tillers $\mathrm{m}^{-2}(85.60)$ and panicle length $(26.93 \mathrm{~cm})$ were recorded from line sowing $\left(\mathrm{S}_{2}\right)$ and it was significantly higher than the plant height $(111.71 \mathrm{~cm})$, number of tillers $\mathrm{m}^{-2}(88.40)$, effective tillers $\mathrm{m}^{-2}$ (82.80) and panicle length (25.80) obtained from the broadcasting $\left(\mathrm{S}_{1}\right)$. At the time of harvesting maximum plant population $\mathrm{m}^{-2}$ (46.87) was recorded from the line sowing $\left(\mathrm{S}_{2}\right)$ and the lowest $(45.53)$ from broadcasting $\left(\mathrm{S}_{1}\right)$. At harvest plant height $(112.92 \mathrm{~cm})$ observed from the seed rate of $120 \mathrm{~kg} \mathrm{ha}^{-1}\left(\mathrm{R}_{5}\right)$ was found to be significantly higher than the rest seed rates. The number of effective tillers/ $\mathrm{m}^{2}$ (89.17) and panicle length $(27.67 \mathrm{~cm})$ were observed from the seed rate of $100 \mathrm{~kg} \mathrm{ha}^{-1}\left(\mathrm{R}_{3}\right)$ which was significantly higher than other seed rates. Test weight was not influenced significantly by the sowing technique as well as seed rate.

\section{Introduction}

The number of plants per unit area has an impact on plant architecture, modifies growth and development pattern and effects on the production photosynthesis (Abuzar et al.,
2011). The increase in plant density increases the yield up to a limit and thereafter a leveling off or decline in yield. The reason for the reduction in yield is due to the reduction in resources per plant. So the reduction in yield will not be compensated by increasing plant 
number. Seed rate has a great impact on plant density and the competitiveness of the crop stand, tiller, time to maturity and yield. Low plant density and improper sowing method are the most important factors of agronomic constraints for obtaining higher yields and have a positive influence on the yield of rice. Optimum plant density is the primary factor for obtaining higher yield in rice. Directseeded rice occupies $26 \%$ of the total rice area in South Asia (Gupta et al., 2006). Direct seeding technique offers a useful option to reduce the limitations of transplanted rice. Repeated puddling adversely affects soil physical properties by dismantling soil aggregates, reducing permeability in subsurface layers, and forming hard-pans at shallow depths which make land preparation becomes difficult and requires more energy to achieve proper soil tilth for succeeding crops. Although, transplanting method of establishment is reported to be the best for higher productivity of rice, but looming water crisis, water-intensive nature of rice cultivation and escalating labour costs drive the search for alternative management methods to increase water productivity and profitability in rice cultivation. Direct seeded rice has received much attention because of its low input demand. Direct seeding of rice avoids puddling, does not need continuous submergence, and thus reduces the overall water demand for rice culture. When rainfall at planting time is highly variable, direct seeding may help reduce the production risk (Singh et al., 2006). Direct seeding can also reduce the risk by avoiding terminal drought that lowers the yield of transplanted rice, especially if the latter is established late due to delayed rainfall. Direct seeding can facilitate crop intensification (Singh et al., 2008). To overcome this problem, direct seeding of rice seems only viable alternatives in rescuing farmers. Keeping the above point in view, the present investigation was carried out to find out the effect of different sowing techniques and different seed rate on growth, yield and economics of direct seeded rice.

\section{Materials and Methods}

Field experiment was conducted during kharif 2016 to study the effect of sowing technique with different seed rate on growth and yield of direct seeded rice (Oryza sativa L.) under rainfed medium land situation. The experiment consists of two sowing techniques (Broadcasting and Line sowing) with five seed rate $\left(80 \mathrm{~kg} \mathrm{ha}^{-1}, 90 \mathrm{~kg} \mathrm{ha}^{-1}, 100 \mathrm{~kg} \mathrm{ha}^{-1}, 110\right.$ $\mathrm{kg} \mathrm{ha}^{-1}$ and $120 \mathrm{~kg} \mathrm{ha}^{-1}$ ) and replicated thrice in factorial randomised block design. The soil of the experimental site was clay in texture with organic carbon (1.15\%), available nitrogen (322 kg ha ${ }^{-1}$ ), available phosphorus $\left(17.59 \mathrm{~kg} \mathrm{ha}^{-1}\right)$ and available potash $(287.17$ $\mathrm{kg} \mathrm{ha}^{-1}$ ). The recommended dose of $\mathrm{N}: \mathrm{P}: \mathrm{K}$ was $60: 40: 30 \mathrm{~kg} \mathrm{ha}^{-1}$. The fertilizers were used in the form of urea, single super phosphate and muriate of potash. Full dose of phosphorous and potash along with half dose of urea were applied uniformly as a basal to all the plots three days before sowing. The remaining half dose of nitrogen was applied in two equal splits at active tillering stage (25 DAS) and panicle initiation stages (65 DAS). Sowing in line was done at a spacing of $20 \mathrm{~cm}$ from row to row. The data were subjected to analysis of variance (ANOVA) with three replication in factorial randomised block design by using excel. The least significant difference (LSD) was calculated in comparing the treatment means at $5 \%$ level of probability.

\section{Results and Discussion}

\section{Effect of sowing technique}

\section{Growth}

From the data it has been observed that the plant height was not significantly influenced by the different sowing techniques at 30 days 
after sowing (DAS). At this stage the highest plant height $(35.70 \mathrm{~cm})$ was recorded from the line sowing $\left(\mathrm{S}_{2}\right)$ and the lowest plant height $(35.65 \mathrm{~cm})$ was observed from broadcasting $\left(S_{1}\right)$. At 60 DAS the plant height was significantly influenced by the different sowing technique. The highest plant height $(88.00 \mathrm{~cm})$ was recorded from the line sowing $\left(\mathrm{S}_{2}\right)$ and the lowest plant height $(87.53 \mathrm{~cm})$ was recorded from the broadcasting $\left(\mathrm{S}_{1}\right)$. Similar trend was observed at 90 DAS. The maximum plant height $(112.17 \mathrm{~cm})$ was recorded from the line sowing $\left(S_{2}\right)$ and the lowest plant height $(111.53 \mathrm{~cm})$ was recorded from the broadcasting $\left(\mathrm{S}_{1}\right)$. At harvesting the plant height $(112.29 \mathrm{~cm})$ recorded from line sowing $\left(\mathrm{S}_{2}\right)$ was significantly higher than the plant height $(111.71 \mathrm{~cm})$ obtained from the broadcasting $\left(\mathrm{S}_{1}\right)$. It may be due to the reason that plants sown in line sowing had a specific distance than broadcasting and the competition between the plants were minimum and deep penetration of roots resulting in efficient nutrient uptake and good plant growth. Similar result was reported by Mehmood et al., (2013) and Ehsanullah et al., (2007). From the data it has been observed that the number of tillers $\mathrm{m}^{-2}$ was not influenced significantly by the different sowing techniques at 30 DAS. At 30 DAS the maximum number of tillers $\mathrm{m}^{-2}$ (35.80) was recorded from the line sowing $\left(\mathrm{S}_{2}\right)$ and the lowest from broadcasting $\left(\mathrm{S}_{1}\right)$. At 60 DAS the maximum number of tillers $\mathrm{m}^{-2}$ (88.40) recorded from the line sowing $\left(\mathrm{S}_{2}\right)$ was found to be significantly higher than the number of tillers $\mathrm{m}^{-2}$ (86.73) observed from broadcasting $\left(\mathrm{S}_{1}\right)$ (Table 1). In the same trend at 90 DAS the maximum number of tillers $\mathrm{m}^{-2}$ (89.80) recorded from the line sowing $\left(\mathrm{S}_{2}\right)$ was significantly higher than the number of tillers $\mathrm{m}^{-2}$ (88.20) obtained from broadcasting $\left(\mathrm{S}_{1}\right)$. At harvesting the significantly higher number of tillers $\mathrm{m}^{-2}$ (90.40) was recorded from the line sowing $\left(\mathrm{S}_{2}\right)$ and the lowest number of tillers $\mathrm{m}^{-2}$ (88.40) from broadcasting $\left(\mathrm{S}_{1}\right)$.

\section{Plant population $/ \mathrm{m}^{2}$}

From the data it has been observed that the plant population was not influenced significantly by the different sowing techniques at 30 DAS. At 30 DAS the maximum plant population $\mathrm{m}^{-2}$ (47.93) was recorded from the line sowing $\left(\mathrm{S}_{2}\right)$ and the lowest plant population $\mathrm{m}^{-2}$ (47.27) was observed from broadcasting $\left(\mathrm{S}_{1}\right)$. A perusal of the data in Table 2 revealed that effect of sowing techniques had significant effect on the plant population $\mathrm{m}^{-2}$ at harvesting. Maximum plant population $\mathrm{m}^{-2}$ (46.87) was recorded from the line sowing $\left(\mathrm{S}_{2}\right)$ and the lowest plant population $\mathrm{m}^{-2}(45.53)$ was observed from broadcasting $\left(\mathrm{S}_{1}\right)$.

\section{Yield attributes}

The number of effective tillers $\mathrm{m}^{-2}$ was influenced significantly by different sowing techniques. Maximum number of effective tillers $\mathrm{m}^{-2}$ (85.60) recorded from the line sowing $\left(\mathrm{S}_{2}\right)$ was found to be significantly higher than broadcasting (82.80). Panicle length was significantly influenced by the different sowing techniques. Panicle length $(26.93 \mathrm{~cm})$ recorded from the line sowing $\left(S_{2}\right)$ was significantly higher than the panicle length $(25.80 \mathrm{~cm})$ observed from broadcasting $\left(\mathrm{S}_{1}\right)$. Similar result was reported by Aslam et al., (2008). Test weight was found to be nonsignificant between the different sowing techniques. Highest test weight $(29.53 \mathrm{~g})$ was recorded from the line sowing $\left(\mathrm{S}_{2}\right)$ and the lowest test weight $(29.40 \mathrm{~g})$ was observed from broadcasting $\left(\mathrm{S}_{1}\right)$. Similar type of result was reported by Tahir et al., (2007).

\section{Yield}

Grain yield (5682.84 $\mathrm{kg} \mathrm{ha}^{-1}$ ) obtained from the line sowing $\left(\mathrm{S}_{2}\right)$ was significantly higher than the yield recorded from broadcasting $\left(5430.62 \mathrm{~kg} \mathrm{ha}^{-1}\right)$. Grain yield of rice 
increased with the increase in the number of plants per unit area as long as there is space in the cultivated areas. When planting density exceeds an optimum level, competition among plants for light above ground and for nutrients below ground becomes severe. Consequently, plant growth slow and grain yield decreases. Similar results were reported by Zeng and Shannon, 2000 who reported that the reduction in fertility at high density was one of the causes for the reduction of seed yield per plant with the increase of seeding density. But the straw yield was not influenced significantly by the sowing techniques (Table $3)$.

Highest straw yield $\left(9802.27 \mathrm{~kg} \mathrm{ha}^{-1}\right)$ was recorded from the line sowing $\left(\mathrm{S}_{2}\right)$ and the lowest straw yield $\left(9619.20 \mathrm{~kg} \mathrm{ha}^{-1}\right)$ was observed from broadcasting $\left(\mathrm{S}_{1}\right)$. Highest straw yield was due to more number of tillers $\mathrm{m}^{-2}$ and more plant population $\mathrm{m}^{-2}$ which attributed to increase cumulative mean value of temperature and sunshine hour. Similar result was reported by Muhammad et al., (2007). Harvest index (36.69 \%) recorded from the line sowing $\left(S_{2}\right)$ was significantly higher than the broadcasting (36.07\%). It might be due to higher economic yield. Similar result was reported by Mehmood et al., (2013).

\section{Effect of seed rate}

\section{Growth}

Plant height was not significantly influenced by the different seed rated at 30 DAS. At this stage maximum plant height $(35.82 \mathrm{~cm})$ was observed from the seed rate of $120 \mathrm{~kg} \mathrm{ha}^{-1}$ $\left(\mathrm{R}_{5}\right)$ and the lowest plant height $(35.50 \mathrm{~cm})$ from the seed rate of $80 \mathrm{~kg} \mathrm{ha}^{-1}\left(\mathrm{R}_{1}\right)$. At 60 DAS maximum plant height $(88.67 \mathrm{~cm})$ recorded from the seed rate of $120 \mathrm{~kg} \mathrm{ha}^{-1}\left(\mathrm{R}_{5}\right)$ was found to be significantly higher than the remaining treatments except the seed rate of $110 \mathrm{~kg} \mathrm{ha}^{-1}\left(\mathrm{R}_{4}\right)$. Similar trend was also observed at 90 DAS. Maximum plant height $(112.82 \mathrm{~cm})$ was observed from the seed rate of $120 \mathrm{~kg} \mathrm{ha}^{-1}\left(\mathrm{R}_{5}\right)$ and the lowest $(110.88 \mathrm{~cm})$ from the seed rate of $80 \mathrm{~kg} \mathrm{ha}^{-1}\left(\mathrm{R}_{1}\right)$. At harvest plant height $(112.92 \mathrm{~cm})$ observed from the seed rate of $120 \mathrm{~kg} \mathrm{ha}^{-1}\left(\mathrm{R}_{5}\right)$ was found to be significantly higher than the rest seed rates. It might be due to higher plant density and competition for light. At this stage the plant height obtained from seed rate of 110 $\mathrm{kg} \mathrm{ha}^{-1}\left(\mathrm{R}_{4}\right)$ was found to be at par with that of seed rate $100 \mathrm{~kg} \mathrm{ha}^{-1}\left(\mathrm{R}_{3}\right)$. Plant height obtained from seed rate of $80 \mathrm{~kg} \mathrm{ha}^{-1}\left(\mathrm{R}_{1}\right)$ was found to be at par with that of seed rate $90 \mathrm{~kg}$ $\mathrm{ha}^{-1}\left(\mathrm{R}_{2}\right)$. It indicates that when the plant spacing becomes closer (high seeding rate), the plant tends to grow taller in search of light.

That means as the number of plant $\mathrm{m}-2$ increases, plant competes severely for light. Thus, the plants grow taller. This result is in consistent with those reported by Zhang et al., (2006). Number of tillers produced at 30 DAS was not influenced significantly by the different seed rates. Maximum number of tillers $\mathrm{m}^{-2}$ (36.17) was observed from the seed rate of $120 \mathrm{~kg} \mathrm{ha}^{-1}\left(\mathrm{R}_{5}\right)$ and the lowest (34.83) from the seed rate of $80 \mathrm{~kg} \mathrm{ha}^{-1}\left(\mathrm{R}_{1}\right)$. At 60 DAS maximum number of tillers $\mathrm{m}^{-2}$ (93.83) observed from the seed rate of $120 \mathrm{~kg} \mathrm{ha}^{-1}$ $\left(R_{5}\right)$ was found to be at par with that of number of tillers $\mathrm{m}^{-2}$ (92.50) obtained from $110 \mathrm{~kg} \mathrm{ha}^{-1}\left(\mathrm{R}_{4}\right)$.

The number of tillers $\mathrm{m}^{-2}$ recorded from $\mathrm{R}_{4}$ (92.50) and $R_{5}$ (93.83) was significantly higher than the rest seed rates. Similar trend was also observed at 90 DAS. Maximum number of tillers $\mathrm{m}^{-2}$ (94.17) was observed from the seed rate of $120 \mathrm{~kg} \mathrm{ha}^{-1}\left(\mathrm{R}_{5}\right)$ and the lowest number of tillers $\mathrm{m}^{-2}$ (81.50) from the seed rate of $80 \mathrm{~kg} \mathrm{ha}^{-1}\left(\mathrm{R}_{1}\right)$. At harvest also the number of tillers $\mathrm{m}^{-2}$ recorded from the seed rate of $R_{4}$ (93.17) and $R_{5}$ (94.17) were found to be at par but significantly higher than the rest seed rates. 
Table.1 Effect of sowing technique and seed rate on plant height and number of tillers $/ \mathrm{m}^{2}$ at different growth stages of rice

\begin{tabular}{|l|c|c|c|c|c|c|c|c|}
\hline Treatment & \multicolumn{4}{|c|}{ Plant height (cm) } & \multicolumn{3}{c|}{ Number of tillers/m² } \\
\cline { 2 - 8 } & $\begin{array}{c}30 \\
\text { DAS }\end{array}$ & $\begin{array}{c}60 \\
\text { DAS }\end{array}$ & 90 DAS & Harvest & $\begin{array}{c}30 \\
\text { DAS }\end{array}$ & 60DAS & 90DAS & Harvest \\
\hline
\end{tabular}

\section{Sowing technique}

\begin{tabular}{|c|c|c|c|c|c|c|c|c|}
\hline $\mathbf{S}_{\mathbf{1}}$ & $35.65^{\mathrm{a}}$ & $87.53^{\mathrm{a}}$ & $111.53^{\mathrm{a}}$ & $111.71^{\mathrm{a}}$ & $35.33^{\mathrm{a}}$ & $86.73^{\mathrm{a}}$ & $88.20^{\mathrm{a}}$ & $88.40^{\mathrm{a}}$ \\
\hline $\mathbf{S}_{\mathbf{2}}$ & $35.70^{\mathrm{a}}$ & $88.00^{\mathrm{b}}$ & $112.17^{\mathrm{b}}$ & $112.29^{\mathrm{b}}$ & $35.80^{\mathrm{a}}$ & $88.40^{\mathrm{b}}$ & $89.80^{\mathrm{b}}$ & $90.40^{\mathrm{b}}$ \\
\hline $\mathbf{S . E m}(\mathbf{\pm})$ & 0.11 & 0.13 & 0.13 & 0.10 & 0.20 & 0.55 & 0.48 & 0.46 \\
\hline $\begin{array}{c}\mathbf{C . D .} \\
\mathbf{P = 0 . 0 5}\end{array}$ & NS & 0.40 & 0.40 & 0.30 & NS & 1.64 & 1.43 & 1.38 \\
\hline
\end{tabular}

\section{Seed rate}

\begin{tabular}{|c|c|c|c|c|c|c|c|c|}
\hline $\mathbf{R}_{1}$ & $35.50^{\mathrm{a}}$ & $86.83^{a}$ & $110.88^{a}$ & $111.10^{\mathrm{a}}$ & $34.83^{\mathrm{a}}$ & $78.33^{a}$ & $81.50^{a}$ & $82.50^{\mathrm{a}}$ \\
\hline $\mathbf{R}_{2}$ & $35.55^{\mathrm{a}}$ & $87.50^{b}$ & $111.28^{\mathrm{a}}$ & $111.50^{\mathrm{a}}$ & $35.50^{\mathrm{a}}$ & $83.33^{b}$ & $85.83^{b}$ & $86.67^{b}$ \\
\hline $\mathbf{R}_{\mathbf{3}}$ & $35.73^{a}$ & $87.67^{b c}$ & $111.93^{b}$ & $112.05^{b}$ & $35.50^{\mathrm{a}}$ & $89.83^{c}$ & $90.67^{c}$ & $90.50^{c}$ \\
\hline $\mathbf{R}_{4}$ & $35.77^{a}$ & $88.17^{\mathrm{cd}}$ & $112.35^{b c}$ & $112.43^{b}$ & $35.83^{\mathrm{a}}$ & $92.50^{d}$ & $92.83^{\mathrm{cd}}$ & $93.17^{d}$ \\
\hline $\mathbf{R}_{\mathbf{5}}$ & $35.82^{a}$ & $88.67^{d}$ & $112.82^{c}$ & $112.92^{c}$ & $36.17^{\mathrm{a}}$ & $93.83^{d}$ & $94.17^{d}$ & $94.17^{d}$ \\
\hline S.Em ( $( \pm)$ & 0.18 & 0.21 & 0.20 & 0.16 & 0.32 & 0.87 & 0.76 & 0.73 \\
\hline $\begin{array}{c}\text { LSD } \\
(\mathbf{P}=\mathbf{0 . 0 5})\end{array}$ & NS & 0.63 & 0.61 & 0.47 & NS & 2.59 & 2.25 & 2.18 \\
\hline \multicolumn{9}{|c|}{ Interaction of $S x R$} \\
\hline $\operatorname{S.Em~}( \pm)$ & 0.25 & 0.30 & 0.29 & 0.22 & 0.46 & 1.23 & 1.07 & 1.04 \\
\hline $\begin{array}{c}\text { LSD } \\
(\mathbf{P}=\mathbf{0 . 0 5})\end{array}$ & NS & NS & NS & NS & NS & NS & NS & NS \\
\hline
\end{tabular}

*Means followed by same superscripts within the same column are not significantly different at $5 \%$ level of probability based on Duncan's Multiple Range. $S_{1}=$ Broadcasting; $S_{2}=$ Line sowing; $R_{1}=80 \mathrm{~kg} / \mathrm{ha} ; R_{2}=90 \mathrm{~kg} / \mathrm{ha} ; R_{3}=100 \mathrm{~kg} / \mathrm{ha} ; \mathbf{R}_{4}=110$ $\mathrm{kg} / \mathrm{ha}$ and $R_{5}=120 \mathrm{~kg} / \mathrm{ha}$ 
Table.2 Effect of sowing technique and seed rate on plant population, yield attributes and yield of rice

\begin{tabular}{|c|c|c|c|c|c|c|c|c|}
\hline Treatment & $\begin{array}{c}\text { Plant } \\
\text { population } / \mathrm{m}^{2} \\
\text { at } 30 \mathrm{DAS}\end{array}$ & $\begin{array}{c}\text { Plant } \\
\text { population } / \mathrm{m}^{2} \\
\text { at harvest }\end{array}$ & $\begin{array}{c}\text { No. of } \\
\text { effective } \\
\text { tillers/m } / \mathbf{m}^{2}\end{array}$ & $\begin{array}{l}\text { Panicle } \\
\text { length } \\
\text { (cm) }\end{array}$ & $\begin{array}{c}\text { Test } \\
\text { weight } \\
\text { (g) }\end{array}$ & $\begin{array}{l}\text { Grain } \\
\text { yield } \\
\text { (kg/ha) }\end{array}$ & $\begin{array}{c}\text { Straw } \\
\text { yield } \\
\text { (kg/ha) }\end{array}$ & $\begin{array}{c}\text { Harvest } \\
\text { index } \\
(\%)\end{array}$ \\
\hline \multicolumn{9}{|c|}{ Sowing technique } \\
\hline $\mathrm{S}_{1}$ & $47.27^{\mathrm{a}}$ & $45.53^{\mathrm{a}}$ & $82.80^{\mathrm{a}}$ & $25.80^{\mathrm{a}}$ & $29.40^{\mathrm{a}}$ & $5431^{\mathrm{a}}$ & $9619^{a}$ & $36.07^{\mathrm{a}}$ \\
\hline $\mathbf{S}_{2}$ & $47.93^{\mathrm{a}}$ & $46.87^{b}$ & $85.60^{b}$ & $26.93^{b}$ & $29.53^{\mathrm{a}}$ & $5683^{b}$ & $9802^{\mathrm{a}}$ & $36.69^{\mathrm{a}}$ \\
\hline S.Em $( \pm)$ & 0.35 & 0.27 & 0.45 & 0.26 & 0.13 & 20.71 & 52.29 & 0.17 \\
\hline $\operatorname{LSD}(\mathbf{P}=0.05)$ & NS & 0.81 & 1.34 & 0.78 & NS & 61.62 & NS & 0.49 \\
\hline \multicolumn{9}{|l|}{ Seed rate } \\
\hline $\mathbf{R}_{1}$ & $39.33^{\mathrm{a}}$ & $37.83^{\mathrm{a}}$ & $79.83^{\mathrm{a}}$ & $25.50^{\mathrm{a}}$ & $29.33^{\mathrm{a}}$ & $5393^{b}$ & $9550^{\mathrm{a}}$ & $36.09^{b}$ \\
\hline $\mathbf{R}_{2}$ & $43.50^{b}$ & $42.17^{\mathrm{b}}$ & $83.00^{\mathrm{b}}$ & $26.00^{\mathrm{ab}}$ & $29.50^{\mathrm{a}}$ & $5673^{d}$ & $9648^{\mathrm{a}}$ & $37.02^{c}$ \\
\hline $\mathbf{R}_{\mathbf{3}}$ & $48.17^{\mathrm{c}}$ & $46.67^{\mathrm{c}}$ & $89.17^{\mathrm{d}}$ & $27.67^{c}$ & $29.83^{\mathrm{a}}$ & $5868^{\mathrm{e}}$ & $9830^{\mathrm{a}}$ & $37.37^{d}$ \\
\hline $\mathbf{R}_{4}$ & $52.33^{d}$ & $50.67^{d}$ & $85.33^{c}$ & $27.00^{b c}$ & $29.50^{\mathrm{a}}$ & $5565^{c}$ & $9748^{a}$ & $36.34^{b c}$ \\
\hline $\mathbf{R}_{5}$ & $54.67^{\mathrm{e}}$ & $53.67^{\mathrm{e}}$ & $83.67^{\mathrm{bc}}$ & $25.67^{\mathrm{a}}$ & $29.17^{\mathrm{a}}$ & $5285^{\mathrm{a}}$ & $9778^{\mathrm{a}}$ & $35.08^{\mathrm{a}}$ \\
\hline S.Em $( \pm)$ & 0.56 & 0.43 & 0.71 & 0.41 & 0.21 & 32.81 & 82.67 & 0.26 \\
\hline LSD (P=0.05) & 1.66 & 1.28 & 2.12 & 1.23 & $\mathrm{NS}$ & 97.43 & NS & 0.78 \\
\hline \multicolumn{9}{|c|}{ Interaction of $S x R$} \\
\hline S.Em ( $( \pm)$ & 0.79 & 0.61 & 1.01 & 0.58 & 0.30 & 46.39 & 116.92 & 0.37 \\
\hline $\operatorname{LSD}(\mathbf{P}=\mathbf{0 . 0 5})$ & NS & NS & NS & NS & $\mathrm{NS}$ & 137.78 & NS & NS \\
\hline
\end{tabular}

\begin{tabular}{|c|c|c|c|c|c|}
\hline \multicolumn{5}{|c|}{ Table.3 Interaction effect of sowing technique and seed rate on grain yield (kg/ha) } \\
\hline & $\mathrm{R}_{1}$ & $\mathrm{R}_{2}$ & $\mathrm{R}_{3}$ & $\mathrm{R}_{4}$ & $\mathrm{R}_{5}$ \\
\hline $\mathbf{S}_{\mathbf{1}}$ & 5208 & 5639 & 5706 & 5436 & 5164 \\
\hline $\mathbf{S}_{\mathbf{2}}$ & 5578 & 5706 & 6030 & 5695 & 5406 \\
\hline S.Em (土) & 46.39 & & & & \\
\hline LSD (P=0.05) & 137.78 & & & & \\
\hline
\end{tabular}

\section{Plant population $/ \mathbf{m}^{2}$}

Plant population $/ \mathrm{m}^{2}(54.67)$ observed from the seed rate of $120 \mathrm{~kg} \mathrm{ha}^{-1}\left(\mathrm{R}_{5}\right)$ was significantly higher than the rest seed rates. The lowest plant population $/ \mathrm{m}^{2}(39.33)$ was observed from the seed rate of $80 \mathrm{~kg} \mathrm{ha}^{-1}\left(\mathrm{R}_{1}\right)$.

Similar trend was also observed at harvest. Maximum plant population $/ \mathrm{m}^{2}$ (53.67) was observed from the seed rate of $120 \mathrm{~kg} \mathrm{ha}^{-1}$ $\left(\mathrm{R}_{5}\right)$ and the lowest plant population $/ \mathrm{m}^{2}$ (37.83) from the seed rate of $80 \mathrm{~kg} \mathrm{ha}^{-1}\left(\mathrm{R}_{1}\right)$.
Yield attributes

The number of effective tillers/ $\mathrm{m}^{2}$ (89.17) observed from the seed rate of $100 \mathrm{~kg} \mathrm{ha}^{-1}$ $\left(\mathrm{R}_{3}\right)$ was significantly higher than other seed rates. The lowest number of effective tillers/ $\mathrm{m}^{2}$ (79.83) was observed from the seed rate of $80 \mathrm{~kg} \mathrm{ha}^{-1}\left(\mathrm{R}_{1}\right)$. Panicle length $(27.67 \mathrm{~cm})$ observed from the seed rate of $100 \mathrm{~kg} \mathrm{ha}^{-1}$ $\left(R_{3}\right)$ was found to be significantly higher than the other seed rates. The lowest panicle length $(25.50 \mathrm{~cm})$ was recorded from the seed rate of $80 \mathrm{~kg} \mathrm{ha}^{-1}\left(\mathrm{R}_{1}\right)$. It may be due to restriction in 
space as the seed rate increased. Increasing seed rate would also increase the number of plants per unit area and results in additional unhealthy seedlings with small panicle length due to competition and enhance the susceptibility to pests and diseases.

Similar result was reported by Harris and Vijayaragavan (2015). Test weight observed from different seed rate was found to be nonsignificant. Highest test weight (29.83 g) was observed from the seed rate of $100 \mathrm{~kg} \mathrm{ha}^{-1}$ $\left(\mathrm{R}_{3}\right)$ and the lowest test weight $(27.17 \mathrm{~g})$ from the seed rate of $120 \mathrm{~kg} \mathrm{ha}^{-1}\left(\mathrm{R}_{5}\right)$. But there was a decreasing trend in thousand grain weight as the seeding rate was increased. It was in conformity with the results of Jan et al., 2002.

\section{Yield}

The different seed rate influenced significantly on the grain yield of rice. Highest grain yield $\left(5868.00 \mathrm{~kg} \mathrm{ha}^{-1}\right)$ was observed from the seed rate of $100 \mathrm{~kg} \mathrm{ha}^{-1}$ $\left(\mathrm{R}_{3}\right)$ and the lowest grain yield $(5284.72 \mathrm{~kg}$ $\mathrm{ha}^{-1}$ ) from the seed rate of $120 \mathrm{~kg} \mathrm{ha}^{-1}\left(\mathrm{R}_{5}\right)$. It may be due to restriction in space as the seed rate increased. Increasing seed rate would also increase the number of plants per unit area and results in additional unhealthy seedlings with less number of panicle due to competition and enhance the susceptibility to pests and diseases.

These findings are supported by Baloch et al., (2002). Straw yield of rice was not influenced significantly by the different seed rate. Highest straw yield $\left(9829.67 \mathrm{~kg} \mathrm{ha}^{-1}\right)$ was observed from the seed rate of $100 \mathrm{~kg} \mathrm{ha}^{-1}$ $\left(\mathrm{R}_{3}\right)$ and the lowest straw yield $(9549.50 \mathrm{~kg}$ $\left.\mathrm{ha}^{-1}\right)$ from the seed rate of $80 \mathrm{~kg} \mathrm{ha}^{-1}\left(\mathrm{R}_{1}\right)$. Maximum harvest index $(37.37 \%)$ was observed from the seed rate of $100 \mathrm{~kg} \mathrm{ha}^{-1}$ $\left(\mathrm{R}_{3}\right)$ and the lowest harvest index $(35.08 \%)$ from the seed rate of $120 \mathrm{~kg} \mathrm{ha}^{-1}\left(\mathrm{R}_{5}\right)$.
Interaction between sowing technique and seed rate

Interaction between the sowing techniques and seed rate had significant effect on grain yield. The highest grain yield (6030.11 $\mathrm{kg} \mathrm{ha}^{-1}$ ) was recorded from the treatment $S_{2} R_{3}$ which was line sowing at the seed rate of 100 $\mathrm{kg} \mathrm{ha}^{-1}$. The lowest interaction effect (5163.89 $\mathrm{kg} \mathrm{ha}^{-1}$ ) was observed from the treatment $S_{1} R_{5}$ which was broadcasting at the seed rate of $120 \mathrm{~kg} \mathrm{ha}^{-1}$. This is in agreement with the studies reported by Akbar et al., 2004. From the above finding it can be concluded that direct seeding of line sowing was found to be superior over the broadcasting at the rate of $100 \mathrm{~kg} \mathrm{ha}^{-1}$ in terms of growth and yield of rice.

\section{Acknowledgement}

The authors are thankful to the Dean, College of Agriculture, CAU, Imphal for providing necessary inputs and technical support to carry out this experiment.

\section{References}

Abuzar, M.R., Sadozai, G.U., Baloch M.S., Shah, A.A., Javaid, T. and Hussain N. (2011). Effect of plant population densities on yield of maize. The $J$. of Ani. and Plant Sci., 21(4), 692-695.

Akbar, N. and Ehsanullah (2004). AgroQualitative Responses of Direct Seeded Fine Rice to Different Seeding Densities, Pak. J. of Agric. Sci., 41, 1-2.

Aslam, M., Hussain, S., Ramzan, M. and Akhter, M. (2008). Effect of different stand establishment techniques on rice yields and its attributes. J. Anim. Plant. Sci., 18(2-3): 80-82.

Baloch, A.W., Soomro, A.M., Javed, M.A. and Ahmed, M. (2002). Optimum plant density for high yield in rice, Asian $J$. Plant Sci., 1: 25-27. 
Delessa, A. (2017). Effect of Sowing Method and Seeding Rate on Yield and Yield Components of Rainfed Rice (Oryza sativa L.) Varieties in Woliso, SouthWest Shoa Zone, Ethiopia. Int. J. Applied Agril. Sci., Vol. 3(5):104-110.

Ehsanullah, N., Akbar, N., Jabran, K. and Habib, T. (2007). Comparison of different planting methods for optimization of plant population of fine rice (Oryza sativa L.) in Pakistan. Pak. J. Agri. Sci., 44(4): 597-599.

Gupta, R.K., Ladha, J.K, Singh, S., Singh, R.G., Jat, M.L., Saharawat, Y., Singh, V.P., Singh, S.S., Singh, G., Sah, G., Gathala, M., Sharma, R.K., Gill, M.S., Alam Murshad, Mujeeb Ur Rehman Hafiz, Singh, U.P., Mann Riaz, Pathak, A., Chauhan, H, Bhattacharya, B.S. and Malik, P.R.K. (2006). Production Technology for direct seeded rice. RiceWheat Consortium for the Indogangetic Plains, pp 16. New Delhi.

Harris, K.D. and Vijayaragavan, R. (2015). Optimum Seed Rate for Maximum yield in Rice (Oryza sativa L.). Res. J. Agric. Forestry Sci., 3(11): 1-5.

Jan, A., Hamid, I. and Muhammad, T.J. (2002). Yield and yield component of wheat as influenced by seeding rates and sowing dates. Pakistan J. Biol. Sci., 3(2): 323-325.

Mehmood, A., Ahmad, A., Ahmed, M., Muhammad, A.A. and Muhammad, A. (2013). Evaluation of Planting Methods for Growth and Yield of Paddy (Oryza sativa L.) Under Agro-Ecological
Conditions of District Shikarpur. American-Eurasian J. Agric. \& Env. Sci., 13 (11): 1503-1508.

Muhammad, A.U., Zaidi, S.A.R., Razzaq, A. and Bokhari, S.D.H. (2007). Effect of planting techniques on paddy yield in salt-affected soil. Int. J. Agri. \& Bio., 1560-8530/09-1-179-180. In: http://www.fspublishers.org.

Singh, S.P., Sreedevi, B., Kumar, R.M. and Subbaiah, S.V. (2008). Grain yield and economics of wet direct sown rice under different establishment methods and nitrogen schedules. Oryza, 45 (3):245246.

Singh, Y.P., Singh, G., Singh, S.P., Kumar, A., Sharma, G., Singh, M.K., Mortin, M. and Johnson, D.E. (2006). Effect of weed management and crop establishment methods on weed dynamics and grain yield of rice. Indian J. Weed Sci., 38 (1 and 2): 20-24.

Tahir, H.A., Ali, I., Safdar, M.E., Ashraf, M.A. and Yaqub, M. (2007). Economic effect of different plant establishment techniques on rice (Oryza sativa L.) production. J. Agric, Res., 45(1): 73-80.

Zeng, L. and Shannon, M.C. (2000). Effects of Salinity on Grain Yield and Yield Components of Rice at Different Seeding Densities. Agron. J., 92: 418423.

Zhang, L., Tao, J., Wang, S., Chang, K. and Wang, T. (2006). The rice Os Rad21.4, an orthologue of yeast $\operatorname{Rec} 8$ protein, is required for efficient meiosis. Plant Mol. Bio., 60(4): 533-554.

\section{How to cite this article:}

Nandini Dev, K., Nilanjana Haldar, Herojit Singh Athokpam, K. Khamba Singh, M. Anandi Devi and Dorendro Singh, A. 2019. Influence of Sowing Techniques and Seed Rate on Growth and Yield of Direct Seeded Rice (Oryza sativa L.) under Rainfed Medium Land Situation. Int.J.Curr.Microbiol.App.Sci. 8(08): 529-536. doi: https://doi.org/10.20546/ijcmas.2019.808.062 